\title{
Tibuana
}

Journal of applied Industrial Engineering-University of PGRI Adi Buana

\section{p-ISSN 2622-2027 \\ $e$-ISSN 2622-2035 \\ REDUCING THE NUMBER OF PACKAGING IN THE CODING PROCESS AT PACKAGING UNIT USING THE SIX SIGMA METHOD}

\author{
Rusdiyantoro ,Yunia Dwie Nurcahyanie(*) \\ Industrial Engineering Study Program, Faculty of Industrial Technology \\ Universitas PGRI Adi Surabaya \\ (*corresponden authore-mail) : yuniadwie@unipasby.ac.id
}

\begin{abstract}
Abstrak
Non-dairy creamer is a product made at PT. NDC as a substitute for milk or cream, which is a fat emulsion product. Krimer is packed with a $25 \mathrm{~kg}$ small bag with an updated coding according to the lot, production time, production date, product name, and packaging date expiration date. Often there is an error in the packaging unit, especially at the coding stage with the wrong non-dairy creamer packaging code that causes packaging defects. The defects in packaging focused on the coding stage, have to be minimized. The research uses the Six Sigma method as a useful tool to increase productivity and product quality. With DMAIC Discussion (Define, Measure, Analyze, Improve, and Control). Through data processing and analysis using the DMAIC cycle obtained three types of packaging defects, namely cryptic code, double code and wrong code from the three defects obtained percentage value of cryptic code $63 \%$, double code $44 \%$ and wrong code $42 \%$ and obtained an average value sigma 3.71 with a DPMO value of 13,553
\end{abstract}

Keywords: Non-Dairy Creamer, Packaging Disability, Six Sigma DMAIC Method

\section{INTRODUCTION}

Non-dairy creamer is a substitute for milk or cream, which is a product of fat emulsions in water. The creamer made from hydrogenated vegetable oils, with the addition of permissible food additives. Functionally, non-dairy creamer has many advantages over dairy creamer, including non-dairy creamer using vegetable oil as a safe source of fat for people with lactose intolerance (Ditahardiyaniet.al., 2008). Non-dairy creamer considered as a substitute for creamers made from raw evaporation milk or fresh milk. This product is referred to as non-vegetable cream or vegetable creamer because it uses vegetable oil as a raw material as well as the use of milk fat in cream products. The problem that often arises related to defects in cream packaging is the occurrence of an incorrect, expired date code that is very detrimental to the company because the wrong code for expiry date packaging can't be used and they must be changed with the new one (Putranto, 2006).

The replacement of new packaging will require more costs for each package, and it takes time, cost, and more energy used for packaging replacement due to the packaging defect (www.santoskrimer.co.id) downloaded 9 January 2018. From these problems, the right method is needed to reduce defects in non-dairy creamer packaging so that the company's losses can be minimized to a minimum, especially in the coding process. The method used in this study is six sigma. The selection of this method is because the six sigma method is far more detailed than the statistical analysis method. Six Sigma can be applied in any business field, from strategic planning to operations to customer service and maximizing motivation for business. 


\section{Tibuana}

\section{RESEARCH METHOD}

\subsection{Research Design}

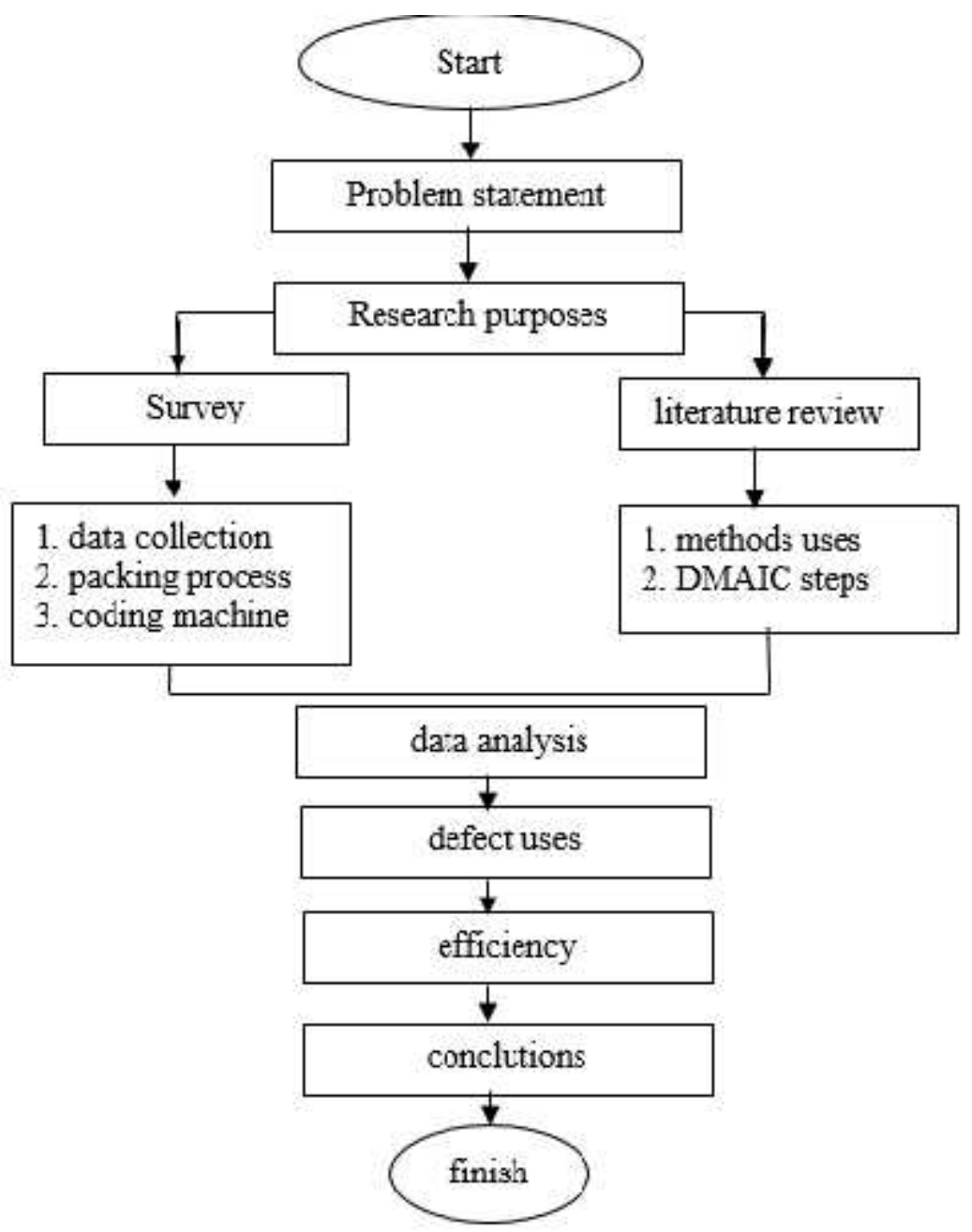

Figure 1. Step of Research

\subsection{Data collection methods}

1. Observation, direct observation in the field or object of research for 15 weeks.

2. Documentation methods to find data on matters of variables in the form of notes, transcripts, books, and so on. From this method, it is expected that data from packaging $25 \mathrm{~kg}$ non-dairy creamer production can be obtained and from the production data can be obtained on the number of packaging defects and causes of packaging defects.

\subsection{Data Analysis Methods}

\subsubsection{Seven Tools}

1. Seven tools of quality are auxiliary tools used in quantitative exploration (statistics) as well as quality experts W. Edwards Deming who 
introduce Statistical Process Control (SPC) or Statistical Quality Control (SQC) based on seven statistical tools (seven tools), namely: observation sheet (check sheet), stratification (run chart), histogram, control chart (control chart), Pareto diagram, cause and effect diagram and scatter diagram. The following explanation of the seven tools used by the author in this study is 3 of 7 tools, namely the observation sheet (check sheet), Pareto diagram, and fishbone diagram (Samadhi, A., Opit, P.F., \& Yudelen, M.I., 2008)

2. X-Bar and $\mathrm{R}$ Full Map, the purpose of making $\mathrm{X}$ and $\mathrm{R}$ control maps is to monitor changes in variable distribution in terms of the concentration location, whether the process is still within the control limits or not and whether the average product produced is following a predetermined standard (Samadhi et.al., 2008)

3. Observation Sheet (Check Sheet)

Check sheet is a data collection and analysis tool.

The purpose of the Check sheet is to facilitate the process of collecting data for particular purposes and present it in a communicative form so that it can convert into information. Form and contents are adjusted to the needs and working conditions that exist, so the data taken must be genuinely following the needs of the analysis. The purpose of making a checking sheet is to ensure that data is collected accurately and accurately by operational employees to be carried out process control and problem-solving. The data in the checking sheet will be used and analyzed quickly and easily (Samadhi et.al., 2008).

4. Pareto diagram

After doing a measure with PChart, it will be known whether there are products that are outside the control limit or not if it turns out that the product is known to be analyzed by using a Pareto diagram to be sorted according to the level of the biggest damage proportion to the smallest. This Pareto diagram will help to focus on the problem of product failures that are more common, which suggests which problems will be of great benefit if handled (Samadhi et.al., 2008).

5. Fish Bone Diagram

Fishbone is a diagram that is used to find all the causal elements that are thought to cause the problem. This diagram can be used to help identify the cause of a problem. The process of identifying causes is done to find many problems that are considered important to overcome. This process includes identifying problems in the input, problems in the process, and problems in the output. So it is known the problems that occur in each activity, where these problems have a role in determining the quality of nondairy creamer with zero defect products (Samadhi et.al., 2008).

\section{b. Application of Product Quality Control Using the Six Sigma Approach}

The method used refers to the principles contained in the six sigma method. This method is used to anticipate the occurrence of errors or disabilities by 


\section{Tibuana}

Journal of applied Industrial Engineering-University of PGRI Adi Buana

p-ISSN 2622-2027

$e$-ISSN 2622-2035

using measurable and structured steps.

Based on existing data, continuous improvement can be made based on the six sigma methodology, which includes DMAIC (Saludin, 2016).

\section{Define}

At this stage, the proportion of disability is determined to be the most significant cause of damage, which is a source of production failure. The way to go is:

a. Identify quality standard problems in producing products that have been determined by the company.

b. Defining an action plan that must be carried out based on the results of observations and analysis of research.

c. Set goals and objectives for improving six sigma quality based on observations.

\section{Measure}

The measurement phase is carried out through 2 stages, with sampling taken by the company as follows:

\section{a. Analysis with diagram control (X- Bar and $\mathbf{R}$ chart)}

The control diagram is used for attributes that are in the properties of goods based on the proportion of the number of events or events such as received or rejected due to the production process. This diagram can be arranged in the following steps:

1. Population or sample collection

a. The population taken for the $P$ Chart analysis is the number of products produced in production activities at PT NDC, namely 25 $\mathrm{kg}$ non-dairy creamer products.

2. Calculating the average value, $X$ bar, and the range of each product mismatch.

3. Calculate the average of all $x$-bars ( $\mathrm{x}$-double bar which is the control line of the $\mathrm{x}$-bar control map), as well as the average value of all $\mathrm{R}$

(R-bar which is the central line of the control $\mathrm{R}$ map).

4. Calculate control limits from the $\mathrm{X}$-bar control map and

R Map X-bar control (3-sigma limit)

CL $\quad=x$-double bar

$\mathrm{UCL} \quad=\mathrm{x}$-double bar $+\mathrm{A} 2 \mathrm{R}$ -

Bar

LCL = x-double bar - A2R-

Bar

R Control Map (3-sigma control limits)

$\mathrm{CL} \quad=\mathrm{R}$ bar

$\mathrm{UCL}=\mathrm{D} 4 \mathrm{R}$ bar

LCL = D3R bar

5. Create a control bar and R map using the control limits above.

\section{b. Analyzing Sigma levels and Defect PerMillion company Opportunities:}

At this step, there are six process were done (Safitri, F., Yunianta, \& Purwatiningrum, 2013). They were:

1. Process need to identifed

2. Total production of the creamer

3. Total rejected packaging

4. Counting failure level and determining failure cause

5. Counting CTQ failure cause

6. Counting CTQ and possibility of DPMO then converting DPMO into sigma value.

\section{Analyze}

Identify the causes of quality problems using:

a. Pareto diagram

After doing a measure with $\mathrm{P}$ Chart, it will be known whether there are products that are outside the control limit or not. If it turns out that the product is known to be analyzed by using a Pareto diagram to be sorted according to 


\section{Tibuana}

Journal of applied Industrial Engineering-University of PGRI Adi Buana

p-ISSN 2622-2027

$e$-ISSN 2622-2035

the level of the biggest damage proportion to the smallest.

b. Cause and Effect Diagram

The causal diagram is used as a technical guideline of the operational functions of the production process to maximize the success values of a company's product quality at the same time by minimizing the risks of failure.

\section{Improve}

Is the stage of improvement in six sigma quality must take measurements (see

\section{RESULTS AND DISCUSSION \\ 3.1 Data Presentation}

Table 1. Data on Packaging Production of Creamer Products (in Bag Units per Week)

\begin{tabular}{|c|c|c|c|c|c|c|}
\hline \multirow[b]{2}{*}{ Weeks } & \multicolumn{5}{|c|}{ Coding defects } & \multirow[b]{2}{*}{$\begin{array}{l}\text { Failure } \\
\text { procentage }\end{array}$} \\
\hline & Production & $\begin{array}{l}\text { Coding } \\
\text { blur }\end{array}$ & $\begin{array}{l}\text { Coding } \\
\text { double }\end{array}$ & $\begin{array}{l}\text { Coding } \\
\text { wrong }\end{array}$ & $\begin{array}{l}\text { total } \\
\text { reject }\end{array}$ & \\
\hline 1 & 11400 & 54 & 42 & 49 & 145 & 1,27 \\
\hline 2 & 11400 & 72 & 42 & 54 & 168 & 1,47 \\
\hline 3 & 10260 & 60 & 54 & 36 & 150 & 1,46 \\
\hline 4 & 11400 & 72 & 30 & 30 & 132 & 1,16 \\
\hline 5 & 11400 & 66 & 48 & 42 & 156 & 1,37 \\
\hline 6 & 10260 & 54 & 54 & 30 & 138 & 1,35 \\
\hline 7 & 11400 & 66 & 42 & 36 & 144 & 1,26 \\
\hline 8 & 11400 & 72 & 60 & 42 & 174 & 1,53 \\
\hline 9 & 10260 & 54 & 42 & 48 & 144 & 1,40 \\
\hline 10 & 11400 & 60 & 48 & 42 & 150 & 1,32 \\
\hline 11 & 11400 & 84 & 42 & 72 & 198 & 1,74 \\
\hline 12 & 11400 & 72 & 48 & 36 & 156 & 1,37 \\
\hline 13 & 11400 & 54 & 48 & 42 & 144 & 1,26 \\
\hline 14 & 10260 & 54 & 24 & 30 & 108 & 1,05 \\
\hline 15 & 11400 & 60 & 36 & 54 & 150 & 1,32 \\
\hline Total & 166440 & 954 & 660 & 643 & 2257 & 1,36 \\
\hline average & 11096 & 63,6 & 44 & 42,87 & 150,47 & 1,36 \\
\hline
\end{tabular}

Data source : PT NDC Sidoarjo

From the table that has been shown, it can be seen the type of defect that often occurs is damaged due to cryptic code with a total number of 954 bags, double code 660 bag, and wrong code 643 bag. Data obtained from observations for 15 weeks with a total production of 1900 bags per day, with a total production of 16.6440 for 15 observations. 


\section{Tibuana}

Journal of applied Industrial Engineering-University of PGRI Adi Buana

3.2 Data Processing

\subsubsection{Stage of Analysis of the Pareto}

Chart

$\%$ Defects $=\frac{\mathrm{T} \quad \mathrm{D} \quad \mathrm{b} \mathrm{t}}{\mathrm{T} \quad \mathrm{D}} \%$
CodingDouble $=\frac{6}{2} \times 100 \%=29.24 \%$

Coding Blur $=\frac{9}{2} \times 100 \%=28.48 \%$

Wrong Code $=\frac{6}{2} \times 100 \%=42.26 \%$

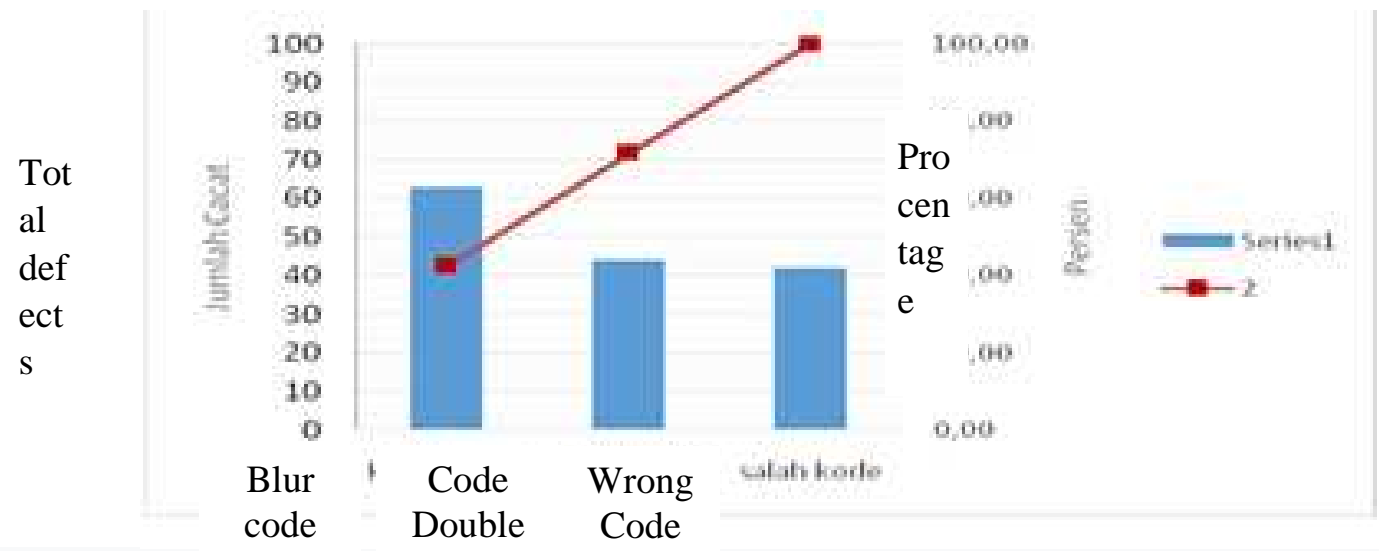

Figure 2 Pareto Diagram of Disability in Non-Dairy Creamer Packaging

From the Pareto diagram above, the type of defect consists of 3 types of defects, namely cryptic code, double code, and wrong code. The main cause of disability is the vague code with an average total defect of 63 bags, and other causes include the double 44 bag code and the wrong code 42 bags. Of the three types of defects, the highest percentage is cryptic code defects with a total percentage of $42.28 \%$, while for the double code $29.53 \%$ and incorrect code $28.19 \%$. Improvements can be made by focusing on one of the biggest causes of disability. This is because one type of defect is a problem of product quality control at PT NDC for the packaging process at the coding stage.

\subsubsection{Analysis Phase Control Chart (X-} Bar and $R$ chart) a. Map of Control X

b. Full R Map

$$
\begin{aligned}
& \begin{array}{rl}
\mathrm{UCL} & =\mathrm{X}+\mathrm{A}_{2} \cdot \mathrm{RUCL}=\mathrm{D}_{4} \cdot \mathrm{R} \\
& =50,15+(1,023 \cdot 26) \\
=2,574 & .26 \\
& =50,15+26,598=66,924 \\
& =76,748 \\
\mathrm{C}=\mathrm{R} & =26 \\
\mathrm{CL}=\mathrm{X} & =50 \cdot 15 \mathrm{LCL}=\mathrm{D}_{3} \cdot \mathrm{R} \\
\mathrm{LCL} & =\mathrm{X}-\mathrm{A}_{2} \cdot \mathrm{R} \\
& =0.26 \\
& =50,15-(1,023 \cdot 26) \\
& =0 \\
& =50,15-26,598 \\
& =23,552
\end{array}
\end{aligned}
$$




\section{Tibuana}

Journal of applied Industrial Engineering-University of PGRI Adi Buana

p-ISSN 2622-2027

$e$-ISSN 2622-2035
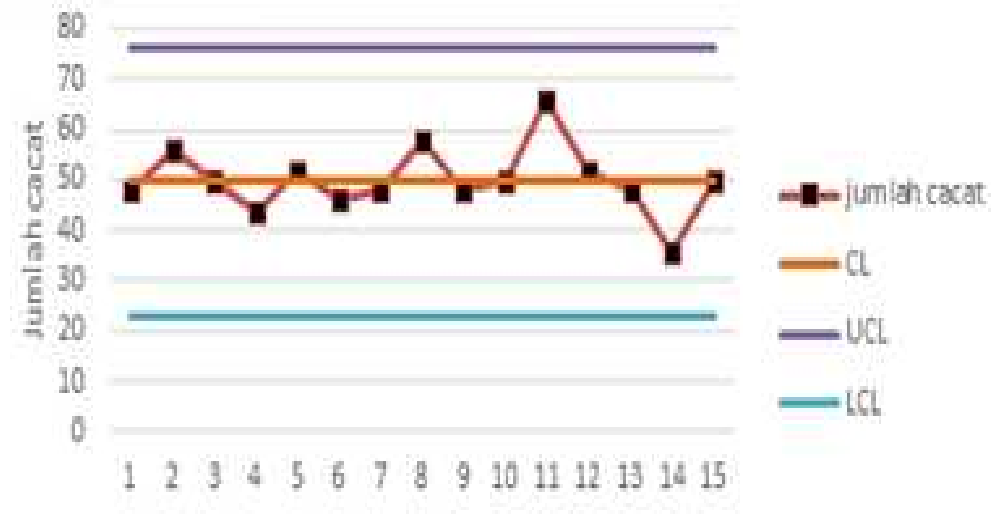

123456789101112131415

Figure 3 Full X Map

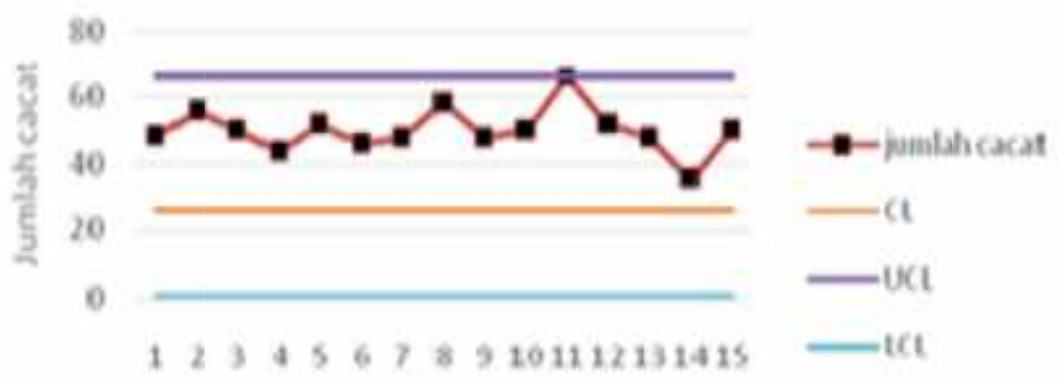

Figure 4 Full R Map

From Figure 3 and 4 of the $\mathrm{X}$ and $\mathrm{R}$ control maps, it is known that all data are not outside the control or out of control limits, so there is no need to revise as seen from the graph above.

\subsubsection{Analysis of Causal Diagrams}

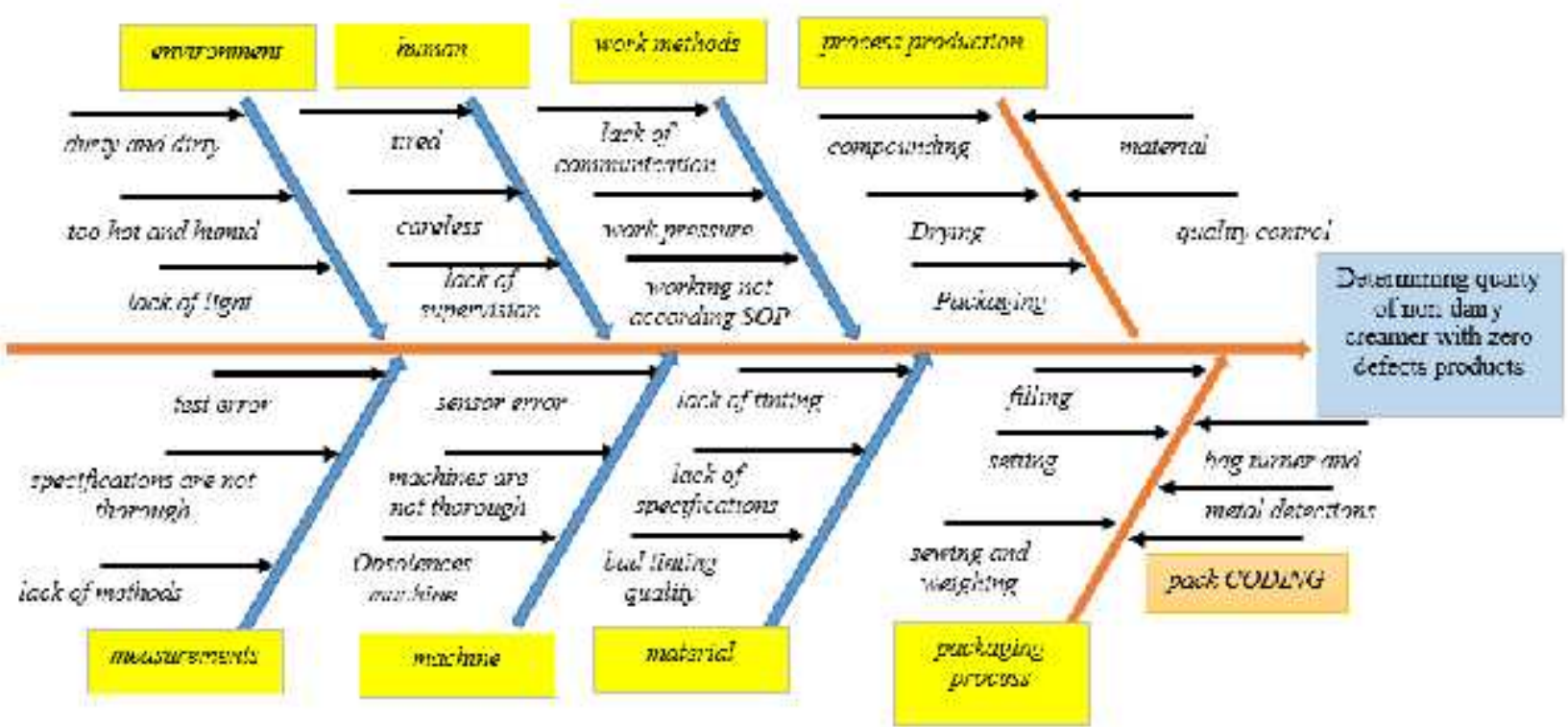

Figure 5 Cause Diagram Due to Defective Packaging Codes 


\section{Tibuana}

Journal of applied Industrial Engineering-University of PGRI Adi Buana

p-ISSN 2622-2027

$e$-ISSN 2622-2035

3.3.4 Stage of Measurement of Sigma and DPMO

Counting DPU (Defect Per

Unit)

$\mathrm{DPU}=\frac{T \quad R}{T \quad P}$

DPU (Defect Per Unit) at the first week

0.012719298

$\mathrm{DPU}=\frac{1}{1}=$

Counting DPMO ( Defect

Per Million Oportunities)

DPMO =

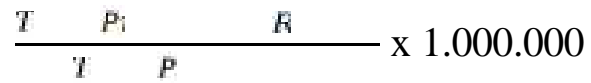

DPMO (Defect Per Miliion

Oportunities) at the first week

$=12719.29825$

\subsection{Analysis of Results and Settlement 3.3.1 Define}

At this stage is the first step in the six sigma approach the first thing to do is to identify the things that are considered important in the coding process, in the coding process in packaging at this stage the packaging that is defective in the coding is defined as the cause. Based on existing problems, 3 causes of the highest failure product can be defined, namely vague code, double code, wrong code. The packaging defect problem in the coding process, there are three stages, namely defining the problem, defining the action plan, and setting goals and objectives. Defining packaging defect problems can be seen in the following table:

Table 2. DPMO Creamer Packaging

\begin{tabular}{cccccc}
\hline weeks & $\begin{array}{c}\text { Total } \\
\text { defects }\end{array}$ & $\begin{array}{c}\text { Total } \\
\text { Production }\end{array}$ & $\begin{array}{c}\text { DPU }=\text { Total Defects/ } \\
\text { Total Production }\end{array}$ & $\begin{array}{c}\text { DPMO }= \\
\text { DPUx 1000000 }\end{array}$ & $\begin{array}{c}\text { Sigma } \\
\text { level }\end{array}$ \\
\hline 1 & 145 & 11400 & 0,0127 & 12719,30 & 3,74 \\
2 & 168 & 11400 & 0,0147 & 14736,84 & 3,68 \\
3 & 150 & 10260 & 0,0146 & 14619,88 & 3,68 \\
4 & 132 & 11400 & 0,0116 & 11578,95 & 3,77 \\
5 & 156 & 11400 & 0,0137 & 13684,21 & 3,71 \\
6 & 138 & 10260 & 0,0135 & 13450,29 & 3,71 \\
7 & 144 & 11400 & 0,0126 & 12631,58 & 3,74 \\
8 & 174 & 11400 & 0,0153 & 15263,16 & 3,66 \\
9 & 144 & 10260 & 0,0140 & 14035,09 & 3,7 \\
10 & 150 & 11400 & 0,0132 & 13157,89 & 3,72 \\
11 & 198 & 11400 & 0,0174 & 17368,42 & 3,61 \\
12 & 156 & 11400 & 0,0137 & 13684,21 & 3,71 \\
13 & 144 & 11400 & 0,0126 & 12631,58 & 3,74 \\
14 & 108 & 10260 & 0,0105 & 10526,32 & 3,81 \\
15 & 150 & 11400 & 0,0132 & 13157,89 & 3,72 \\
total & 2257 & 166440 & 0,0136 & 13560,44 & 55,7 \\
average & 150,47 & 11096 & 0,0136 & 13560,44 & 3,71 \\
\hline
\end{tabular}

Data Source: PT NDC Sidoarjo 


\subsubsection{Measure}

The measure is a measurement stage which divided into two stages, namely the diagram control analysis stage and the Sigma level measurement stage, and Defects Per Million Opportunities (DPMO). Data were taken from PT DNC, namely quality control measured from the number of final products. Measurements made with $\mathrm{X}$ and $\mathrm{R}$ control maps of production from January 2017 to April 2017, which is a sample size of 15 . The type of sample used is a coded packaging that has a defect. The number of packaging production produced from January 2017 to April 2017 was 166,440 bags, and defective products found from the three leading causes of disability were 2,257 bags.

\subsubsection{Analyze}

Analyze is the third stage for improving quality by identifying causes of damage, namely Pareto diagrams and causal diagrams. The leading cause of disability is the vague code with an average total defect of 63 bags, and other causes include the double 44 bag code and the wrong code 42 bags. Of the three types of defects, the highest percentage is hidden code defects with a total percentage of $42.28 \%$, while for the binary code $29.53 \%$ and incorrect code $28.19 \%$. Improvements made by focusing on one of the biggest causes of disability, because one type of defect is a problem of product quality control at PT NDC for the packaging process at the coding stage. So the repairs that must be made first are packaging code defects are vague; this is because the packaging defects are the most significant number of defects compared to other packaging defects.

\subsubsection{Improve}

After knowing the causes of packaging defect coding in the packaging of PT NDC, a recommendation or proposed corrective action prepared, the results of the analysis and general corrective actions to reduce the level of product damage as follows:

\section{a. Analysis Results}

1. The machine is the main factor causing packaging defects due to the lack of repair, maintenance, and supervision of the engine.

2. Acceptance of raw materials that are not following the standards of ink raw materials.

3. Storage of irregular raw materials and not according to the composition should be.

4. Packaging defects do not get reasonable control by the supervisor.

5. Lack of operator or employee awareness of packaging defects and lack of handling skills.

\section{b. Corrective actions took}

1. Quality control in the packaging process in the packaging unit includes all stages of the packaging machine that have the potential to cause defects in the packaging.

2. More intensive and continuous supervision of packaging machine performance and the stages of the machine in the packaging process, especially the coding machine, which is the main object of this research. The machines are cleaned every end of the packaging every day, and machine testing is done once a week to make sure the coding machine can be used correctly every day.

3. Make written SOPs related to attitude work and related communication to minimize packaging defects, to be carried out by all employees, both supervisors, operators, and other subordinates. 


\subsubsection{Control}

It is the final analysis stage of the Six Sigma project that emphasizes documenting and disseminating the actions taken, including.

1. The packaging section, especially the coding section, always pays attention to all the leader's instructions.

2. Perform maintenance and repair of packaging machines, especially coding machines regularly.

3. Supervise ink raw materials, packaging materials or paper bags and employees of the coding section so that the quality of goods or products produced better.

4. All who participate in the packaging should improve discipline.

5. Record data on all defective products every day from each type and machine carried out by employees in the production process.

6. Report the results of recording the data on defective products based on the type of product recorded to the head of a production.

7. The total number of defective products in one month was included in the damage report book for the responsibility of the supervisor to report to the company leader.

\section{CONCLUSION}

Based on the results of the research and analysis of the data discussed in the previous chapter, conclusions taken as follows:

The packaging production of PT NDC has an average level of sigma 3.71 with a DPMO value of 13,553 which can be interpreted that from the one million opportunities there will be 13,553 possibilities that the process for a million production, sigma values can be seen from the DPMO convention table. Defining quality problems with the Six Sigma final product quality control system, there are three causes of the highest packaging defects, namely $63 \%$ secret code, $44 \%$ binary code, and $42 \%$ incorrect code.

\section{REFERENCES}

1. Ditahardiyani, P., Ratnayani, \& Angwar, M., (2008). The Quality Improvement Of Primer Packaging Process Using Six Sigma Methodology. Yogyakarta: Jurnal Pengembangan Teknologi Kimia Dan Ilmu Pengetahuan Indonesia, 10(2) 177-184.

2. Putranto, J.A.B., (2006). Pengembangan Produk Krimer NonSusu (Non-Dairy Creamer) Berbasis Kelapa Sawit. Bogor: Institut Pertanian.

3. Safitri, F., Yunianta, \& Purwatiningrum, I., (2013). Pengaruh Penambahan Pati Termodifikasi Pada Non Dairy Creamer Terhadap Stabilitas Emulsifikasi Dan Efisiensi Sodium Caseinate. Malang: Jurnal Pangan Dan Agroindustri, 1(1) 1-14.

4. Saludin. (2016). Panduan Pengerjaan Proyek Six Sigma. Jakarta:

Mitra Wacana Media.

5. Samadhi, A., Opit, P.F., \& Yudelen, M.I., (2008). Penerapan SixSigma Untuk Meningkatkan Kualitas Produk Bimoli Classic: Studi Kasus PT. Salim Ivomas Pratama di Bitung. Manado: Jurnal Teknik Industri, Vol.III . No, 1.

6. http:/www.santos-krimer.co.id/ind/ (copyright 2008), Downloaded 9 January 2018. 